\title{
Company Law
}

\section{Derivative actions in respect of public listed companies}

\section{by Tony Boyle}

This comment seeks to focus on the significance of civil proceedings as a remedy for corporate abuse in public listed companies. The real need is to ease the path of the minority shareholder litigant and not to make such proceedings more difficult than they would be in the case of private companies. It is open to question whether the proposal in the Law Commission's recent consultation paper Shareholder Remedies (paper 142, see part 16) will in fact achieve this objective.

\section{WHAT IS NEEDED}

Minority shareholders in private companies do not need yet another remedy in the form of a statutory derivative action (as proposed by the Law Commission). That need arises in respect of public listed companies where the decision of the Court of Appeal in Prudential Assurance $v$ Newman Industries (No. 2) [1982] Ch 204 appears to render the 'common law' derivative action redundant. In the case of listed companies, the other sanctions against wrongdoing by directors are either inappropriate (s. 459 petitions) or inapplicable, except in the most unusual circumstances (just and equitable winding up, wrongful trading and disqualification).

At least in the case of fraudulent breaches of directors' fiduciary duties (e.g. bribery or misappropriation of company assets) the new remedy proposed by the Law Commission is selfevidently needed. It is hoped that the Law Commission's proposal will provide a cure for the problems that exist in the common law derivative action. The evidence of the Canadian experience shows that, in a civil litigation climate very similar to that in England, a statutory derivative action will only very occasionally be resorted to by minority shareholders in respect of public listed companies. It is important that a substantial minority shareholder (e.g. a corporate investor or a wealthy individual shareholder) should be able to resort to civil litigation when strongly motivated to do so.

\section{ADEQUACY OF SANCTIONS}

The significance of civil litigation as a means to redress intra-corporate wrongdoing cannot be lightly dismissed. Even the most sophisticated City regulation (e.g. Cadbury/Greenburystyle corporate governance of the workings of the Panel and its Takeover Code) can only be preventative medicine against fraud. Redress which will actually benefit the company (in those situations where it is in reality unable to initiate such proceedings in its own name) will always be needed. Criminal proceedings are not the real solution. Such proceedings often prove impossible to mount or collapse in the course of a trial. Insolvency proceedings clearly only benefit creditors. The delayed outcome of a Department of Trade and Industry (DTI) inspectors' report will not in itself restore the company's money and assets.

If institutional investors are to perform their 'Cadbury' function of sorting out abuse and gross incompetence in listed companies, they would seem to need an adequate sanction in reserve. The ability to threaten derivative proceedings would seem to provide a powerful sanction where recalcitrant directors refuse to respond to pressure from institutional investors. This may prove much more effective than organising a takeover bid or selling the institutional investors' holding and so driving down the share price. It could be argued that the path should be made easier for institutional investors (and other corporate investors) with, say, a $3 \%$ or $5 \%$ holding in a listed plc (either singly or jointly with other institutions).

\section{WOOLF REPORT}

The heavy-handed remedies available under American corporate law (notably SEC regulation and a still active market in derivative litigation funded from the company's coffers) are not needed in Britain. There is nevertheless a clear need for the reform of the existing common law derivative action. Problems still remain about the Law Commission's proposals in the consultation paper Shareholder Remedies. They may receive a very traditionist interpretation by some of the judiciary. This might bring back much of the old law on fraud in a minority in a new guise.

Further, the Law Commission's proposals may be strangled by the DTI under the influence of urgent advice from say, the Confederation of British Industry or the IOD. Another more favourable development (not requiring primary legislation) is that the implementation of the Woolf Report, reforming civil procedure, may provide an alternative route to reform the worst aspects of the existing derivative action. The problem of de facto wrongdoer control of listed companies may well be solved in this way. This would allow a derivative action based on a serious non-ratifiable breach of fiduciary duty to be brought to trial without undue difficulty.

\section{CANADIAN EXAMPLE}

The evidence of the Canadian experience shows that, in a civil litigation climate very similar to that in England, a statutory derivative action will only very occasionally be resorted to by minority shareholders in respect of public listed companies. It is important that a substantial minority shareholder (e.g. a corporate investor or a wealthy individual shareholder) should be able to resort to civil litigation when strongly motivated to do so.

\section{PROBLEMS UNRESOLVED}

In laying down its five guidelines, the Law Commission fails, as with the rest of its proposals on the proposed statutory derivative action, to discriminate in any way between the general run of private companies and public listed companies, large or small. The problem raised by the de facto control of most public listed companies in the context of the new statutory procedure is addressed nowhere. In the earlier part of the paper Shareholder Remedies, where the defects of the existing common law derivative action are carefully analysed, the problem of establishing wrongdoer control is fully 
explored in the light of what Professor Gower described as the 'calamitous' observations of the Court of Appeal in Prudential Assurance v Newman Industries.

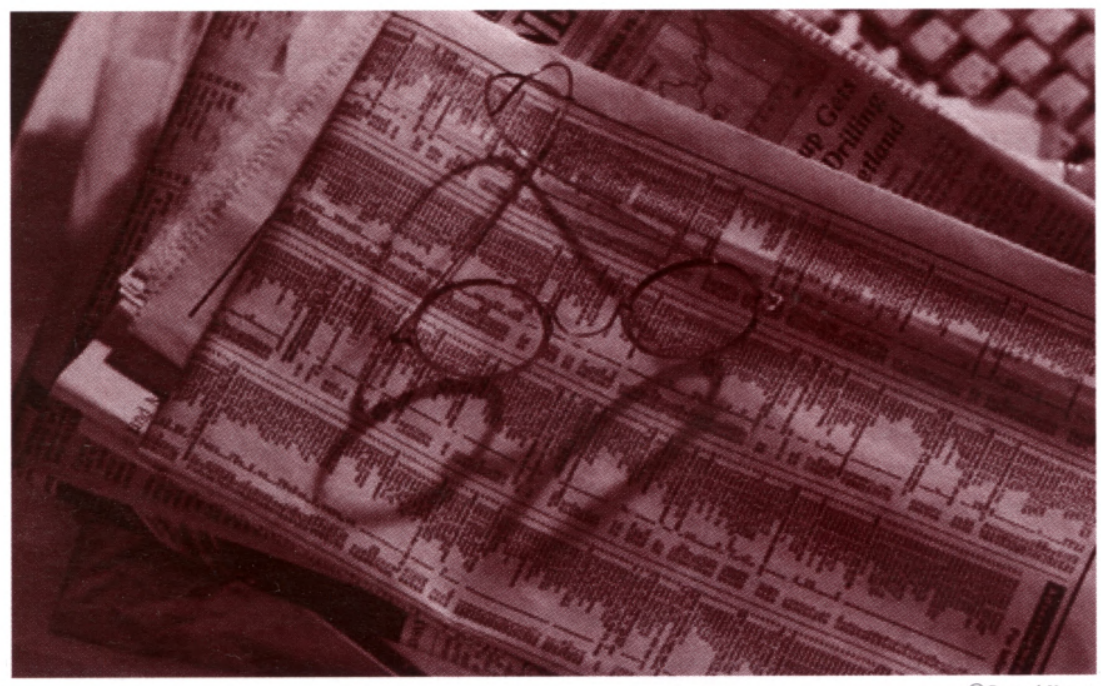

However, the difficulties in the case of public listed companies under de facto control do not entirely disappear when posed in the context of the new statutory remedy. Whether civil litigation in the form of derivative proceedings has a particularly important part to play in the case of just such public listed companies has already been contested. Where an institutional investor (or another substantial corporate shareholder) is seeking to mount such litigation, it is desirable that no unnecessary barrier should obstruct such proceedings. While not going so far as to suggest that a test as to percentage of shareholding (as in the EU Commission's draft fifth directive) should replace the judicial discretion to grant leave, it can be argued that, where an institutional investor (or other substantial investors), either individually or acting jointly holds say, 3\% (or possibly 5\%) of the issued share capital of a listed plc, the judicial discretion to grant leave should tend to be exercised in favour of the applicant. A more thorough scrutiny should be reserved for private companies or individual shareholders in listed companies.

\section{TWO PROBLEM AREAS}

In the particular case of two of the five guidelines (intended to assist the court on an application for leave) problems are likely to occur. These two are ratification and the decision of 'an independent organ'. Shareholder Remedies refers to ratification as a guideline in the grant of leave and in the case management power for the court to order a meeting. In proceedings brought against a listed plc by an institutional or other corporate investor who meets an appropriate percentage requirement, the

(C) Digital Vision

ratification guideline should only be used sparingly. Its application could add very substantially to the delay, costs and adverse publicity of derivative proceedings. There is the further danger that the case law on ratifiable and nonratifiable directors' duties would once more dominate the new statutory derivative action. While the shareholders' power to ratify breaches of duty in general meeting may still have some role in private companies, the ill-attended shareholders' meetings of listed plcs are not an appropriate forum in which carefully weighed decisions about corporate litigation should be made (as the Prudential case well illustrates). In addition, the directors' duty of care and skill might be a very difficult topic about which to litigate successfully.

The 'decision of an independent organ' is an ever more debateable criterion, more especially in the case of a listed plc. As a concept it is not clearly defined in Shareholder's Remedies and was only vaguely delineated in Smith $v$ Croft. It might allow not only a majority of a minority but also a minority of a minority to bar proceedings in substantial private companies. In listed plcs an auditor's report should not be a substitute for the right to litigate. Whether every executive director is, Cadbury-style, judicially detached is also open to question.

In the wrong judicial hands the ability to invoke majority shareholders' power (or other 'independent organ' power) may well enable the worst aspects of the Court of Appeal's decision in Prudential v
Newman Industries to be smuggled back in the exercise of the new statutory discretion to grant leave. In the case of listed plcs it might kill off the use of this remedy at an early stage.

\section{DANGER OF EXCESSIVE CAUTION}

The Law Commission makes this observation (among others) on why it proposes a list of guidelines to assist the court on the application for leave:

'The most important advantage of listing them is that they should assist in building up a body of reported cases which will guide shareholders and advisers.'

In the course of time this will undoubtedly become true. However it may also produce (as did the case law on the old derivative action) over-cautious judicial decisions. This excessive caution may be most in evidence when public listed companies are the subject of derivative proceedings. In such cases, where the new remedy is most needed, great discouragement may be given at an early stage.

\section{IN THE WRONG HANDS}

In the wrong judicial hands the ability to invoke majority shareholders' power (or other 'independent organ' power) may well enable the worst aspects of the Court of Appeal's decision in Prudential v Newman Industries to be smuggled back in the exercise of the new statutory discretion to grant leave. In the case of listed plcs it might kill off the use of this remedy at an early stage.

As contended earlier, institutional investors meeting a percentage test should be given an easier ride. There is all too great a likelihood that all the old Foss $\checkmark$ Harbottle judicial attitudes may be reintroduced in the exercise of the new judicial discretion. De facto wrongdoer control (the great stumbling block in the Prudential litigation) may once more raise its obstinate head, this time in a new guise. In the case of private companies and individual shareholder litigants (where the Law Commission's criteria are much more justified), the need for a new statutory derivative action is much less apparent.

$$
\begin{aligned}
& \text { Tony Boyle } \\
& \text { Queen Mary and Westfield College }
\end{aligned}
$$

